\title{
Kesadaran Hukum Dalam Menafkahi Anak Pasca Putusan Pengadilan
}

Oleh

\section{Agus Anwar Pahutar}

Advokat \& Pusat Mediasi dan Bantuan Hukum APSI Sumbar email : agusanwarsipahutar@iain-padangsidimpuan.ac.id

\begin{abstract}
Abstrac
This paper talks about how the legal awareness of parents (fathers) in providing children after the divorce between Father and Mother in the Religious Court until the child is an adult. From the results of the study found facts in the field that the income or expenditure of children after the divorce between Father and Mother is not carried out effectively and continuously. There are several reasons that arise from my father so that he does not fulfill his obligations in accordance with the order of the decision and the applicable law. Therefore if viewed from the indicator of legal awareness, namely the perspective of the pattern of legal behavior of the husband (father), that the father has not had sufficient legal awareness or legal obedience and is still low, even though they know that giving a child to adulthood or age 21 years is mandatory.
\end{abstract}

Kata Kunci; Kesadaran, Hukum, Nafkah, Putusan, dan Pengadilan.

\section{A. Pendahuluan}

Perceraian dalam rumah tangga merupakan langkah terakhir apabila tidak ditemukan jalan keluar untuk ishlah. Perceraian merupakan suatu hal yang di halalkan Allah SWT namun dibenci-Nya sebagaimana hadis Rasulullah SAW yang diriwayatkan Ibnu Umar :

$$
\text { عن ابن عمر رضي الله عنه ان النبي صلى الله عليه وسلم قال :أبغض الحلال إلى الله الطلاق) رواه ابوا داود ( }
$$

Perceraian membawa berbagai konsekuensi logis yang harus diterima masing-masing pihak termasuk anak, sebab pemeliharaan dan nafkah anak merupakan tanggungjawab kedua orang tua, baik saat kedua orang tuanya masih dalam ikatan perkawinan maupun sudah bercerai.

Undang-undang nomor 1 tahun 1974 juga menjelaskan dalam pasal 41, bahwa akibat putusnya perkawinan karena perceraian baik ibu atau bapak tetap berkewajiban memelihara dan mendidik anak-anaknya semata-mata berdasarkan kepentingan anak, bilamana ada perselisihan mengenai penguasaan anak-anak, pengadilan memberi keputusan; bapak yang bertanggung jawab atas semua biaya pemeliharaan dan pendidikan yang diperlukan anak itu, bilamana bapak tidak sanggup memberikan kewajiban tersebut pengadilan dapat menentukan bahwa ikut memikul biaya tersebut; Pengadilan dapat mewajibkan kepada bekas suami untuk memberikan biaya penghidupan dan/atau menentukan sesuatu kewajiban bagi bekas isteri. 
Dalam pasal 45 ayat 1 menyebutkan bahwa: Kedua orang tua wajib memilihara dan mendidik anak-anak mereka sebaik-baiknya; Kewajiaban orang tua yang dimaksud dalam ayat 1 berdiri sendiri. Kewajiban mana berlaku terus meskipun perkawinan antara kedua orang tua putus;

Dengan demikian, berdasarkan undang-undang di atas sangat jelas bahwa hak anak untuk tidak di abaikan pasca perceraian kedua orang tuanya adalah mutlak, hal tersebut juga sejalan dengan apa yang dijelaskan dalam firman Allah SWT dan Hadis Rasulullah SAW. Surat al-Baqarah ayat 233 "Para ibu hendaklah menyusukan anak-anaknya selama dua tahun penuh, Yaitu bagi yang ingin menyempurnakan penyusuan. dan kewajiban ayah memberi Makan dan pakaian kepada Para anak dengan cara ma'ruf. seseorang tidak dibebani melainkan menurut kadar kesanggupannya. janganlah seorang ibu menderita kesengsaraan karena anaknya dan seorang ayah karena anaknya, dan warispun berkewajiban demikian. apabila keduanya ingin menyapih (sebelum dua tahun) dengan kerelaan keduanya dan permusyawaratan, Maka tidak ada dosa atas keduanya. dan jika kamu ingin anakmu disusukan oleh orang lain, Maka tidak ada dosa bagimu apabila kamu memberikan pembayaran menurut yang patut. bertakwalah kamu kepada Allah dan ketahuilah bahwa Allah Maha melihat apa yang kamu kerjakan". \{Qs. al-Baqarah :233\}. Hadits riwayat dari Aisyah R.A.

$$
\begin{aligned}
& \text { حديث عائشة أن هند بنت عتبة فقالت يارسول الله إن أبا سفيان رجل شحيح وليس يعطيني ما يكفيني }
\end{aligned}
$$

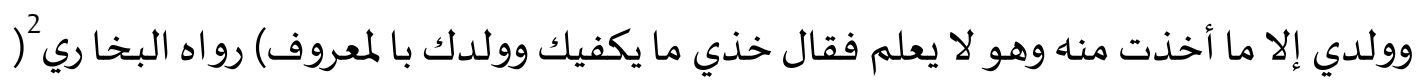

Artinya: Riwayat dari Aisyah, bahwa Hindun binti Itbah berkata: "Wahai Rasulullah SAW, sesungguhnya Abu Sufyan (Suamiku) seorang laki-laki yang amat kikir, ia tidak memberikan nafkah sesuatu yang mencukupi dan anakku, kecuali aku mengambilnya (sendiri) sementara dia tidak mengetahui. Maka beliau bersabda :" ambilah apa yang dapat mencukupi kebutuhanmu dan anakmu secara makruf" \{HR. Bukhari\}.

Meskipun ayat dan hadist tersebut secara eksplesit menegaskan bahwa tanggung jawab pemliharaan anak menjadi beban yang harus dipenuhi suami sebagai ayah, namun pembebanan ayah untuk memberi makan dan pakaian paran ibu melekat di dalamnya, dalam tanggung jawab pemiliharaan anak. Makna hal tersebut dapat dipahami dari ilustrasi bahwa apabila anak tersebut disusukan oleh wanita lain yang bukan ibunya sendiri, maka ayah bertanggung jawab untuk membayar perempuan yang menyusui secara makruf sebagaimana ketentuan pasal 41 poin a dan b, pasal 45 ayat 1 UU. No. 1 tahun 1974 jo pasal 77 ayat 3, pasal 80 ayat 4 Poin b dan c, pasal 104 ayat 1 dan pasal 105 poin c KHI. ${ }^{3}$ 
Sehubungan dengan terjadinya perceraian antara ayah dan ibu, dalam hal ini seorang ayah mengajukan permohonan talak ke Pengadilan Agama (PA) atau sebaliknya isteri yang menggugat cerai suami, dalam proses di persidangan tidak jarang terjadi istri cenderung memperjuangkan haknya sebagai seorang isteri yang akan diceraikan oleh suaminya, ia juga berusaha semaksimal mungkin memperjuangkan pula hak-hak anaknya yang antara lain berupa nafkah anak untuk masa yang akan datang. Karena adanya kekhawatiran bahwa ayah dari anak-anaknya akan melalaikan tanggung jawabnya tersebut setelah terjadinya perceraian antara ayah dan ibu. Adanya kelalaian seorang ayah untuk memberi nafkah kepada anakanaknya yang menyebabkan anak menjadi terlantar, merupakan permasalahan yang sering terjadi di dalam masyarakat, meskipun sering didengar ungkapan sang ayah di persidangan bahwa bila terjadi perceraian, ia akan bertanggungjawab terhadap nafkah anak-anaknya tidak hanya di dunia bahkan juga di akhirat, sungguh suatu ungkapan yang indah terdengar namun keyataanya tidak demikian.

Sehubungan dengan itu, penulis ingin menelusuri bagaimana realisasi putusan pengadilan dalam hal kesadaran atau kepatuhan mantan suami untuk membayarkan nafkah anak pasca tercadinya putusan perceraian dari Pengadilan Agama Pariaman ${ }^{4}$. Sebab, dari Tahun 2014 putusan yang keluar di Pengadilan Agama tentang nafkah anak sebanyak 271 putusan, dari 271 putusan tersebut penulis mengambil 5 sampel untuk diteliti, Pertama, Putusan Nomor: 0290/Pdt.G/2014/PA.Prm, Kedua, putusan Nomor: 002/Pdt.G/2014/PA.Prm, Ketiga, putusan Nomor:0433/Pdt.G/2014/PA.Prm, Keempat, putusan Nomor: 0302/Pdt.G/2014/PA.Prm, Kelima, putusan Nomor: 0411/Pdt.G/2014/PA.Prm.

Selanjutnya, pada tahun 2015 PA Padangpariaman mengeluarkan putusan yang mempersoalkan nafkah anak sebanyak 567 putusan, 5 putusan dari 567 penulis jadikan sebagai sampel. Pertama, putusan Nomor: 0206/Pdt.G/2015/PA.Prm, Kedua, putusan Nomor: 093/Pdt.G/2015/PA.Prm, Ketiga, putusan Nomor: 0304/Pdt.G/2015/PA.Prm, Keempat, putusan Nomor: 068/Pdt.G/2015/PA.Prm, Kelima, putusan Nomor: 0331/Pdt.G/2015/PA.Prm.

\section{B. Paradigma Kesadaran Hukum}

Kesadaran hukum merupakan sikap dan perilaku yang ditunjukkan secara wajar oleh seseorang (manusia) secara umum, sebagai bentuk kesadaran pada adanya pemahaman terhadap hukum, yang didasarkan karena adanya hak dan kepentingan manusia tentang apa arti dan seharusnya hukum itu, dan bagaimana mematuhi maupun mentaati hukum tanpa 
harus ada unsur paksaan. Kesadaran hukum adalah suatu penilaian terhadap apa yang dianggap sebagai hukum yang baik dan atau hukum yang tidak baik. ${ }^{5}$

Dalam ilmu hukum dikenal ada beberapa pendapat tentang kesadaran hukum. Perihal kata atau pengertian kesadaran hukum ada juga yang merumuskan bahwa sumber satusatunya dari hukum dan kekuatan mengikat hukum adalah kesadaran hukum dan keyakinan hukum individu, merupakan pangkal dari pada kesadaran hukum masyarakat. ${ }^{6}$

Jadi, kesadaran hukum merupakan cara pandang masyarakat terhadap hukum itu, apa yang seharusnya dilakukan dan tidak dilakukan terhadap hukum, penghormatan terhadap hakhak orang lain (tenggang rasa) baik ada unsur paksaan maupun tidak ada unsur paksaaan.

Kesadaran hukum terbagi menjadi dua, yaitu; pertama, kesadaran hukum positif, identik dengan ketaatan hukum, dan kedua, kesadaran hukum negatif, identik dengan ketidaktaatan hukum. ${ }^{7}$ Seseorang yang mengetahui akan suatu peraturan hukum, mengetahui maksud dari hukum tersebut, namun orang tersebut tidak mau mematuhi aturan itu, maka seseorang tersebut mempunyai kesadaran hukum yang negatif. Jadi, kesadaran hukum itu adalah menyangkut persoalan apakah ketentuan hukum tersebut dipatuhi atau tidak, baik ia dipaksa maupun secara suka rela.

Ada beberapa faktor yang menyebabkan masyarakat mematuhi hukum, yaitu: Pertama, Compliance yang diartikan sebagai suatu kepatuhan yang didasarkan pada harapan akan suatu imbalan dan usaha untuk menghindarkan diri dari hukum atau sanksi yang mungkin dikenakan apabila seseorang melanggar ketentuan hukum. Kepatuhan ini sama sekali tidak didasarkan pada suatu keyakinan pada tujuan kaidah hukum yang bersangkutan dan lebih didasarkan pada pengendalian dari pemegang kekuasaan. Sebagai akibat kepatuhan hukum akan ada apabila ada pengawasan yang ketat terhadap pelaksanaan kaidah-kaidah hukum tersebut. Kedua, identification yaitu terjadi apabila kepatuhan terhadap kaidah hukum ada bukan karena nilai intriksinya, akan tetapi agar keanggotaan kelompok tetap terjaga serta ada hubungan baik dengan mereka yang diberi wewenang untuk menerapkan kaidah-kaidah hukum tersebut. Daya tarik untuk patuh adalah keuntungan yang diperoleh dari hubunganhubungan tersebut sehingga kepatuhan tergantung pada baik buruknya interaksi tadi. Ketiga, internatization yaitu seseorang mematuhi kaidah-kaidah hukum dikarenakan secara instrinsik kepatuhan tadi mempunyai imbalan. Isi kaidah-kaidah tersebut adalah sesuai dengan nilainilai diri pribadi yang bersangkutan atau oleh karena dia mengubah nilai-nilai yang semula 
dianutnya. Keempat, kepentingan-kepentingan para warga masyarakat terjamin oleh wadah hukum yang ada. ${ }^{8}$

Ide tentang kesadaran hukum warga-warga masyarakat sebagai sahnya hukum positif tertulis ditemukan dalam ajaran-ajaran tentang rechtsgefuhl atau rechtsbewustszijn yang intinya adalah bahwa tidak ada hukum yanng mengikat warga-warga masyarakat kecuali atas dasar kesadaran hukum. ${ }^{9}$

\section{Indikator Kesadaran Hukum}

Parameter dari kesadaran hukum merupakan petunjuk-petunjuk yang jelas tentang adanya taraf kesadaran hukum tertentu. Adapun indikator dari kesadaran hukum tersebut adalah: Pertama, pengetahuan tentang peraturan-peraturan hukum. Pengetahuan hukum adalah pengetahuan seseorang mengenai beberapa perilaku tertentu yang diatur oleh hukum. Sudah tentu hukum yang dimaksud di sini hukum tertulis dan tidak tertulis. Pengetahuan tersebut berkaitan dengan perlilaku yang dilarang dan diperbolehkan oleh hukum. Sebagaimana dapat dilihat dalam masyarakat bahwa pada umumnya seseorang mengetahui bahwa membunuh, mencuri dan lain sebagainya dilarang oleh hukum. ${ }^{10}$

Jadi, Pengetahuan terhadap undang-undang merupakan satu indikator bahwa seseorang itu dapat memiliki kesadaran dalam menjalankan atau melaksanakan hukum tersebut, misalnya pengetahuan masyarakat terhadap UU. Nomor 1 Tahun 1974 tentang Perkawian, sehingga dengan mengetahui peraturan perundang-undangan tersebut masyarakat merasa bahwa undang-undang tersebut harus dipatuhi dan dilaksanakan sebagaimana seharusnya.

Kedua, pemahaman tentang isi peraturan-peraturan hukum. Pemahaman hukum merupakan suatu pengertian terhadap isi dan tujuan dari suatu hukum tertentu, baik tertulis maupun tidak tertulis, serta manfaatnya bagi pihak-pihak yang kehidupannya di atur oleh peraturan tersebut. ${ }^{11}$

Jika dilihat dalam pasal 2 ayat 1 UU. Nomor. 1 tahun 1974 Tentang Perkawinan menjelaskan bahwa "tiap-tiap perkawinan dicatat menurut peraturan perundanganperundangan yang berlaku". Pada pasal 5 Kompilasi Hukum Islam (KHI) juga dijelaskan bahwa "agar terjamin ketertiban perkawinan bagi masyarakat Islam setiap perkawinan harus dicatat". Artinya, dengan mengetahui isi dan tujuan dari pada undang-undang tersebut kesadaran masyarakat untuk mencatatkan pernikahannya akan terlaksana sebagaimana kehendak hukum tersebut. 
Ketiga, sikap terhadap peraturan-peraturan hukum, Sikap hukum merupakan suatu kecendrungan untuk menerima hukum karena adanya penghargaan terhadap hukum sebagai suatu bermanfaat atau menguntungkan jika hukum itu ditaati. Suatu sikap hukum akan melibatkan pilihan warga terhadap hukum yang sesuai dengan nilai-nilai yang ada dalam dirinya sehingga akhirnya warga masyarakat menerima hukum berdasarkan penghargaan terhadapnya. Suatu norma hukum akan dihargai oleh warga masyarakat apabila ia telah mengetahui, memahami dan mentaatinya. Artinya ia benar-benar dapat merasakan bahwa hukum tersebut dapat menghasilkan ketertiban serta ketentraman dalam dirinya. Hukum tidak hanya berkaitan dengan segi lahiriah dari manusia akan tetapi juga dari segi batiniyah. ${ }^{12}$

Keempat, pola-pola perikelakukan hukum atau kepatuhan hukum, dalam hal ini ada beberapa sebab yang menyebabkan hukum tersebut dipatuhi: (1) Takut karena sanksi negatif apabila hukum dilanggar (2) Untuk menjaga hubungan baik dengan pengusaha (3) Untuk menjaga hubungan baik dengan rekan-rekan sesamanya (4) Karena hukum tersebut sesuai dengan nilai-nilai yang dianut (5) Kepentingnannya terjamin. ${ }^{13}$

Secara teoritis, faktor keempat merupakan hal yang paling baik. Hal itu disebabkan faktor pertama, kedua dan ketiga, penerapan hukum senantiasa diawasi oleh petugas-petugas tertentu, agar hukum itu benar-benar ditaati di dalam kenyataannya. Seperti pada peraturan perkawinan, bahwa masalah perkawinan ini masih banyak yang diselewengkan oleh masyarakat dikarenakan tidak adanya faktor yang pertama, yaitu adanya sanksi apabila peraturan mengenai perkawinan dilanggar.

Ajaran kesadaran hukum lebih banyak mempermasalahkan kesadaran hukum yang dianggap sebagai mediator antara hukum dengan perilaku manusia baik secara individu maupun kolektif. Oleh karenanya jarang kesadaran hukum lebih menitik beratkan kepada nilai-nilai yang berlaku kepada masyrakat. Sistem-sistem nilai akan menghasilkan patokanpatokan untuk berproses yang bersifat psikologis, antara lain pola-pola berfikir yang menentukan sikap mental menusia, sikap mental yang ada pada hakikatnya merupakan kecendrungan untuk bertingkah laku dan membentuk pola-pola perilaku maupun kaidahkaidah. ${ }^{14}$

Berdasarkan uraian tersebut, maka keempat indikator kesadaran hukum tersebut akan menunjukkan tingkatan-tingkatan pada kesadaran hukum seseorang. Apabila seseorang hanya memenuhi indikator yang pertama, yaitu menngetahui tentang suatu peraturan hukum, maka kesadaran hukumnya sangatlah rendah, begitu seterusnya dengan indikator kedua dan ketiga, 
tentunya indikator yang keempat yaitu pola-pala perikelakukan hukum atau ketaatan hukum adalah sebuah penilaian terhadap kesadaran hukum yang tinggi. Tingginya kesadaran hukum masyarakat, membuat masyarakat pastinya akan mentaati peraturan-peraturan yang berlaku. Begitu pun sebaliknya, apabila kesadaran hukum rendah, maka kemungkinan kecil hukum akan ditaati.

\section{Kesadaran Hukum Dalam Menafkahi Anak Pasca Putusan Pengadilan}

Sebagaimana yang telah dijelaskan dalam pasal 41 dan 45 Undang-Undang No. 1974 Tentang Perkawian, bahwa bapak berkewajiban menanggung segala kebutuhan/nafkah anakanaknya sebelum anak tersebut dewasa, sekalipun terjadi perceraian anatara bapak dengan ibu si anak. Aturan dalam pasal ini tidak seutuhnya terlaksana oleh masyarakat hukum indonesia. Misalanya sejalan dengan itu, terdapat penomena sosial yang terjadi di tengah-tengah masyarakat, bahwa tidak jarang seorang bapak lalai atau tidak mau menjalankan kewajibannya terhadap anaknya sendiri walaupun telah ada putusan pengadilan yang sudah berkekuatan hukum tetap (incrach). Dari penenelusuran penulis pada Tahun 2014 terdapat 271 putusan Pengadilan Agama Pariaman yang terkait tentang nafkah anak ${ }^{15}$, penulis mengambil lima putusan sebagai sampel dalam penelitian ini, Pertama, Putusan Nomor: 0290/Pdt.G/2014/PA.Prm. tentang cerai talak Hermansyah bin Sidi Oesman (PNS) dengan Zulbaiti binti Amirudin dengan membebankan nafkah anak kepada Hermasyah sebesar Rp. 500.000 (lima ratus ribu rupiah) perbulanya sampai anak itu dewasa. Hasilnya setelah wawancara penulis dengan mantan isteri. Mantan Suami hanya membayar nafkah anak yang sebesar Rp. 300.000 (tiga ratus ribu rupiah) perbulannya yang paling banyak, terkadang Rp. 150.000 (seratus lima puluh ribu rupiah) dan Rp. 250.000 (dua ratus lima puluh ribu rupiah) itu pun bila diingatkan, atau anak tersebut menjemputnya ke rumah ayahnya itu sendiri. Pembayaran ini ini tidak sesuai dengan putusan pengadilan agama Pariaman yang membebankan nafkah anak kepada mantan suami sebesar Rp. 500.000 (lima ratus ribu rupiah) perbulanya. $^{16}$ Setelah penulis mewawancarai mantan isterinya penulis mewawancarai langsung dengan mantan suami dan mengatakan:

"Saya mengetahui bahwa pembayaran nafkah anak Rp. 500.000 (lima ratus ribu rupiah) perbulan. Saya juga membenarkan pembayaran nafkah anak perbulannya tidak sesuai dengan putusan Pengadilan Agama Pariaman. Adapun ungkapan dari mantan isteri saya itu tidak benar dalam pembayaran maksimal Rp. 300.000 (tiga ratus ribu rupiah) perbulan, karena terkadang pembayaran pernah maksimalnya Rp. 500.000 (lima ratus ribu rupiah) perbulan, ketika itu anak saya membutuhkan untuk membeli perlengkapan sekolah waktu naik kelas. 


\section{http://jurnal.iain-padangsidimpuan.ac.id/index.php/elqanuniy/index ISSN : 2442-6652 E-ISSN : 2580-7307}

Pelaksanaan pembayaran nafkah anak tidak diberikan kepada mantan isteri, tetapi langsung kepada anak saya", Sedangakn kendalanya adalah: (1) Faktor umur, karena anak masih sekolah dasar (SD), anak saya masih sekolah SD belum cakap tentang prosedur Bank (rekening Bank atau kartu ATM), tetapi jika anak saya sudah SMP dan SMA, maka akan mudah untuk mengirim uang baik untuk keperluan belanja maupun untuk sekolah.(2) Sakit hati kepada ibu anak, Sakit hati pada ibu anak maksudnya adalah saya terasa di zolimi pada putusan perkara ini dan saya tidak mau memberikan nafkah anak itu kepada ibu, karena kalau diberikan kepada ibunya uang itu akan habis. Selanjutnya jika nafkah anak yang diberikan kepada anak itu dimakan oleh ibunya maka saya mengharamkannya. (3) Alamat tempat anak begitu jauh dari tempat tinggal ayah dan kesibukan pekerjaan di instansi di kota padang" ${ }^{17}$

Kedua, putusan Nomor: 002/Pdt.G/2014/PA.Prm tentang cerai talak yang diajukan oleh Sutri Jon bin Yahya (PNS) dengan Hendra binti Rustam, bahwa putusan hakim memutuskan nafkah satu orang anak sebesar Rp. 500.000 ( liama ratus ribu rupiah) perbulan sampai anak tersebut dewasa berumur 21 tahun. Hasilnya melalui wawancara penulis dengan mantan isteri, Mantan suami hanya membayar sebesar Rp. 500.000 (seratus ribu rupiah) perbulan tiga kali, terkadang Rp. 300.000 (tiga ratus ribu rupiah) perbulan dan selanjutnya sebayak Rp. 400.000 (empat ratus ribu rupiah) perbulan sampai sekarang, dan permberiaan nafkah tersebut anaklah yang harus menjemput ke rumah ayahnya, sedangkan putusan Pengadilan Agama Pariaman membebankan nafkah anak sebesar Rp. 500.000 (lima ratus ribu rupiah) perbulannya. ${ }^{18}$ Kemudian penulis melakukan wawancara langsung dengan mantan suami, bahwa mantan suami mengatakan:

"Saya mengetahui membayar nafkah anak perbulannya dengan jumlah yang ditetapkan putusan Pengadilan Agama Pariaman sebanyak Rp. 500.000 (Lima ratus ribu rupiah) dan saya tetap membayarnya, tapi hanya tiga bulan sesuai dengan putusan hakim. Selanjutnya terkadang saya bayar Rp. 400.000 (empat ratus ribu rupiah) dan Rp. 300.000 (tiga ratus ribu rupiah). Adapun uraian dari mantan isteri saya di atas juga tidak benar, sebab membayar nafkah anak adalah kewajiban dunia akhirat. Pembayaran Rp. 300.000 (tiga ratus ribu rupiah) perbulan itu ada penambahan, seperti pembelian pakaian untuk kebutuhan anak saya, misalnya Pakaian sekolah dan pakaian hari raya." Sedakan kendalanya adalah: (1) Keterlambatan gajian di kantor, saya berkerja di Dinas Kesahatan Kabupaten Padang Pariaman sebagai pegawai Sopir dan gaji perbulannya sering terlambat. (2) Faktor umur, anak saya masih sekolah SD dan belum cakap tentang prosedur ( rekening Bank atau kartu ATM), tetapi apabila anak sudah SMP dan SMA maka akan mudah untuk mengirim uang belanjanya melalui ATM. (3) Sakit hati kepada ibu anak, Sakit hati sama ibu anak maksudnya adalah saya tidak suka terhadap perangai mantan isteri. (4) Alamat tempat anak saya begitu jauh dari tempat tinggal saya dan kesibukan pekerjaan. Alamat anak saya, Korong Simpang Kamumuan Nagari Kuranji Hilir Kecamatan Sungai Limau Kabupaten Padang Pariaman. Alamat saya, Desa Kampung Baru Kecamatan Pariaman Tengah Kota pariaman. Jadi, jaraknya jauh dari desa ke Kota". ${ }^{19}$ 


\section{http://jurnal.iain-padangsidimpuan.ac.id/index.php/elqanuniylindex ISSN : 2442-6652 E-ISSN : 2580-7307}

Ketiga, putusan Nomor:0433/Pdt.G/2014/PA.Prm tentang cerai talak yang diajukan oleh Nasrul bin Nurlis (Sopir) dengan Yeni Warti binti Syaripuddin bahwa putusan hakim memutuskan nafkah satu orang anak sebesar Rp. 300.000 (tiga ratus ribu rupiah) perbulan sampai anak tersebut dewasa berumur 21 tahun. Hasilnya melalui wawancara penulis dengan mantan isteri. Mantan suami hanya membayar sebesar Rp. 100.000 (seratus ribu rupiah) perbulan, terkadang Rp. 150.000 (seratus lima puluh ribu rupiah) perbulan dan terkadang tidak sama sekali, sedangkan putusan pengadilan agama Pariaman membebankan nafkah anak sebesar Rp. 300.000 (tiga ratus ribu rupiah) perbulannya. ${ }^{20}$ Kemudian penulis melakukan wawancara langsung dengan mantan mertua isteri (Ramaidar) karena mantan suaminya merantau ke Pekanbaru, ia mengatakan:

"Mantan suami/Nasrul anak saya pergi merantau ke Pakanbaru. Tentang nafakah anak Nasrul/saya sudah tahu bahwa hakim menetapkannya Rp. 300.000 (tiga ratus ribu rupiah) perbulan. Masalah nafkah anak saya sebagai neneknya Haikal (anak Nasrul) yang bertanggung jawab, sebab Nasrul di Pakanbaru. Pembayaran nafkah anak kadang-kandang Nasrul juga mengirim untuk anaknya sebanyak Rp. 150.000 (seratus lima puluh ribu rupiah) dan terkadang Rp. 100.000 (saratus ribu rupiah) perbulan. Jika Nasrul tidak mengirim, maka saya yang mebayarnya, itupun apabila ada uang. Cara pelaksanaan pembayarannya anak Nasrul bernama Haikal itu dijeput kerumah ibunya dan atau di kirim melalui orang lain. Pembayarannya terkadang diberikan sebanyak Rp. 100.000 (sartus ribu rupiah) dan terkadang Rp. 150.000 (seratus lima puluh ribu rupiah) itupun tidak tiap bulan hanya tergantung kepada ekonomi". Sedangkan yang menjadi kendala adalah: (1) Faktor ekonomi, sebab Nasrul tidak memiliki uang dan sumber mata pencarian yang tetap. (2) Nasrul sudah memiliki isteri baru Sebab, untuk menafkahi isteri yang barunya saja belum cukup, apalagi untuk mengirim nafkah anaknya. (3) Nasrul masih merasakan sakit hati kepada ibu anak, Sakit hati sama ibu anak maksudnya adalah Nasrul tidak suka terhadap perangai mantan isteri yang mengakibatkan perceraian. (4) Alamat tempat anak begitu jauh dari tempat tinggal saya (Ibu ayah (Nenek)) apalagi Nasrul tinggal di Pakanbaru. ${ }^{21}$

Keempat, putusan Nomor: 0302/Pdt.G/2014/PA.Prm tentang cerai talak yang diajukan oleh Chairul bin ST. Chalel (Nelayan) dengan Risnawati binti M. Arif, bahwa putusan hakim memutuskan nafkah satu orang anak sebesar Rp. 500.000 (lima ratus ribu rupiah) perbulannya sampai anak tersebut dewasa berumur 21 tahun. Hasilnya melalui wawancara penulis dengan mantan isteri, mantan suami hanya membayar sebesar perbulan Rp. 400.000 (empat ratus ribu rupiah) perbulan, itupun hanya satu kali setelah perceraian dan sampai sekarang tidak pernah lagi, sedangkan putusan pengadilan agama sebesar Rp. 500.000 (lima ratus ribu rupiah) perbulannya ${ }^{22}$ Kemudian penulis melakukan wawancara langsung dengan mantan suami, kemudian ia mengatakan: 


\section{http://jurnal.iain-padangsidimpuan.ac.id/index.php/elqanuniy/index ISSN : 2442-6652 E-ISSN : 2580-7307}

"Saya mengetahui bahwa pembayaran nafkah anak Rp. 500.000 (lima ratus ribu rupiah) perbulan. Tetapi saya hanya membayar Rp. 400.000 (empat ratus ribu rupiah) perbulan 1 kali dan sampai sekarang tidak pernah. seperti yang telah diungkapkan oleh mantan isteri saya. Pembayaran nafkah anak satu kali pernah dibayar Rp. 400.000 (empat ratus ribu rupiah) dan sampai sekarang tidak pernah lagi". Sedangkan yang menjadi kendalanya adalah: "(1) Faktor ekonomi, sebab saya tidak memiliki uang dan sumber mata pencarian yang tetap. (2) Saya sudah memiliki steri baru, untuk menafkahi isteri yang baru saja belum cukup apalagi untuk memberi nafkah kepada anak. (3) Alamat tempat anak saya jauh dari tempat tinggal saya sehingga saya susah mengantarnya ketika ada uang. ${ }^{23}$

Kelima, putusan Nomor: 0411/Pdt.G/2014/PA.Prm tentang cerai talak yang diajukan oleh Ilham Wijaya bin Soewandi (Pedagang) dengan Nera Ofrianti binti Osaman Umar, bahwa putusan hakim memutuskan nafkah satu orang anak sebesar Rp. 500.000 (lima ratus ribu rupiah) perbulan sampai anak tersebut dewasa berumur 21 tahun. Hasilnya melalui wawancara penulis dengan mantan isteri, mantan suami hanya membayar sebesar Rp. 100.000 (seratus ribu rupiah) perbulan dan terkadang tidak dibayarkan, sedangkan putusan pengadilan agama membebankan sebesar Rp. 500.000 (lima ratus ribu rupiah) perbulannya. ${ }^{24}$ Kemudian penulis melakukan wawancara langsung dengan mantan suami dan ia mengatakan:

"Saya mengetahui bahwa kewajiban membayar nafkah anak sebanyak Rp. 500.000 (lima ratus ribu rupiah) perbulan. Tetapi saya hanya membayar $R p .100 .000$ (Seratus ribu rupiah) perbulan dan pembayaran itu dua kali setelah putusan. Selanjutnya sampai sekarang tidak lagi. Apa yang dikatakan oleh mantan isteri saya itu benar tentang pembayaran nafkah anak pernah dibayar sebesar Rp. 100.000 (Seratus ribu rupiah) perbulan dan pembayaran itu dua kali setelah putusan". Sedangkan yang menjadi kendalanya adalah: "(1) Hakim membebankan nafkah anak terlalu banyak sehingga berat bagi saya untuk membayarnya. (2) Saya tidak memiliki uang dan sumber mata pencarian yang tetap, dulu pedagang dan sekarang pengangguran. (3) saya dianggap meninggal oleh Mantan Isteri saya yang memberikan pengertian kepada anak bahwa saya ayahnya sudah tiada atau meninggal (4) Saya masih merasakan sakit hati kepada mantan isteri. Sakit hati saya adalah selalu berkata kotor dan carut-marut ketika memintak uang untuk anaknya. ${ }^{25}$

Pada Tahun 2015 Pengadilan Agama Pariaman mengeluarkan 567 putusan, ${ }^{26}$ dari 567 putusan tersebut penulis ambil lima putusan sebagai samapel dalam penelitian ini. Pertama, putusan Nomor: 0206/Pdt.G/2015/PA.Prm, tentang perkara cerai talak antara Almi bin Usman (pedagang) dengan Reci Putri Yulisa Binti Mahyunis, bahwa putusan hakim memutuskan nafkah anak satu orang minimal Rp. 1.000 .000 (satu juta rupiah) setiap bulan sampai anak tersebut dewasa berumur 21 tahun. Hasilnya penulis melalui wawancara dengan mantan isteri, mantan suami membanyar sebesar Rp. 500.000 (lima ratus ribu rupiah) perbulan itupun harus diingatkan oleh mantan isteri baru diberikan oleh ayah si anak kepada anaknya dan terkadang tidak diberikan sama sekali dalam beberapa bulan, sedangkan putusan Pengadilan Agama 
Pariaman membebankan minimal Rp. 1.000 .000 (satu juta rupiah) setiap bulan. ${ }^{27}$ Kemudian penulis melakukan wawancara langsung bersama mantan suami melalui handphone, karena ketika penulis ke rumah mantan suami hanya bertemu dengan ibunya dan mengatakan "Almi bekerja di Pakanbaru" kemudian penulis menghubungi dengan handphone dan mantan suami mengatakan:

"Saya sudah mengetahui bahwa kewajiban nafkah anak yang dibebankan hakim kepada saya sebanyak Rp. 1.000 .000 (satu juta rupiah) perbulan. Adapun ungkapan dari mantan isteri saya itu benar pembanyaran nafkah sebesar Rp. 500.000 (lima ratus ribu rupiah) dan itu pernah saya bayar dua kali. Kemudian Rp. 400.000 (empat ratus ribu rupiah) dan setelah itu tidak ada lagi, karena saya jauh dari anak saya. Saya di Pakanbaru dan anak saya di Pariaman." Sedangkan yang menjadi kendalanya adalah: "(1) Karena faktor umur anak masih kecil (umur 5 tahun). (2) Karena saya masih merasakan sakit hati kepada mantan steri terhadap pristiwa perceraian ini. (3) Karena anak saya jauh dari tempat saya. maksudnya saya di Pakanbaru sedangkan anak saya di Kampung Pariaman. Adapun dari segi ekonomi saya tidak memiliki kendala, sebab saya berdagang dengan tetap "Alhamdulillah" ada untuk menafkahi. ${ }^{28}$

Kedua, putusan Nomor: 093/Pdt.G/2015/PA.Prm tentang cerai talak yang diajukan oleh Syafril bin Manshur (Swasta) dengan Yuliana binti Disa, bahwa putusan hakim memutuskan nafkah tiga orang anak sebesar Rp. 3.000.000 (tiga juta rupiah) perbulan sampai anak tersebut dewasa berumur 21 tahun. Hasilnya melalui wawancara penulis dengan mantan isteri, mantan suami hanya membayar sebesar Rp. 500.000 (lima ratus ribu rupiah) perminggu. Sehingga empat minggu dalam satu bulan sebanyak Rp.2.000.000 (dua juta rupiah) perbulan dan itupun tidak tetap, sedangkan putusan Pengadilan Agama Pariaman sebesar Rp. 3.000 .000 (tiga juta rupiah) perbulan. ${ }^{29}$ Kemudian penulis melakukan wawancara langsung dengan mantan suami, ia mengatakan:

"Saya sudah mengetahui tentang jumlah pembayaran nafkah anak sebanyak Rp. 3.000.000 (tiga juta rupiah) perbulan sampai anak tersebut dewasa berumur 21 tahun. Saya sudah membayarnya per-minggu sebesar Rp. 500.000 (lima ratus ribu rupiah), tetapi terkadang ada juga Rp. 600.000 (enama ratus ribu rupiah) perminggu dan itu diberikan kepada mantan isteri samapai sekarang". Kemudian yang menjadi kendalanya adalah: "(1) Karena faktor ekonomi, saya hanya memiliki pekerjaan Swasta (kontraktor), jadi uang yang didapatkan sesuai dengan proyek kontraktor. (2) Karena saya sering keluar daerah sehingga jauh dari anak, biasanya satu kali dalam seminggu bertemu dengan anak-anak dan terkadang satu kali dalam dua minggu sehingga pembayarannya terlambat. ${ }^{30}$

Ketiga, putusan Nomor: 0304/Pdt.G/2015/PA.Prm tentang cerai talak yang diajukan oleh Afrizal bin Armen (sopir) dengan Kurni Yanti Binti Yohanes, bahwa putusan hakim memutuskan nafkah dua orang anak sebesar Rp. 800.000 (delapan ratus ribu rupiah) perbulan sampai anak tersebut dewasa berumur 21 tahun. Hasilnya melalui wawancara penulis dengan 
mantan isteri, mantan suami tidak pernah membayar sesuai dengan putusan Pengadilan Agama Pariaman itu. ${ }^{31}$ Kemudian penulis melakukan wawancara dengan mantan suami melalui handphone, dan ia mengatakan:

"Saya sduah tahu bahwa kewajiban membayar nafkah anak dari penetapan hakim sebesar Rp. Rp. 800.000 (delapan ratus ribu rupiah) perbulan sampai anak tersebut dewasa berumur 21 tahun. Adapun ungkapan dari mantan isteri bahwa tentang pembayaran nafkah anak perbulannya tidak pernah dibayar kepada mantan isteri, tetapi pembeyaran nafkah anak itu diberikan langsung kepada anak. Seperti sewaktu mengantarkan anak ke sekolah dan terkadang pergi jalan-jalan sama anak-anak ke Bukittingi dan lainnya. Tetapi pembayaran nafkah anak dalam satu bulan itu mememang tidak sesuai dengan keputusan hakim yang telah diputuskan sebanyak Rp. 800.000 (delapan ratus ribu rupiah) perbulan, sebab mata pencarian saya tidak tetap. Jadi pemberian nafkah anak itu hanya saya berikan sebanyak Rp. 200.0000 (dua ratus ribu rupiah) perbulan, terkadang Rp.300.000 (tiga ratus ribu rupiah) perbulannya dan samapai sekarang". Kemudian yang menjadi kendala adalah: "(1)Karena faktor ekonomi. alasannya, saya tidak memiliki uang dan sumber mata pencarian yang tetap, hanya sebagai sopir. (2) Saya sudah memiliki steri baru. Sebab, untuk menafkahi steri yang baru saja belum cukup, apalagi untuk memberikan nafkah anak dari mantan steri" ${ }^{32}$

Keempat, putusan Nomor: 068/Pdt.G/2015/PA.Prm tentang cerai talak yang diajukan oleh Mhd. Yusuf bin Ruslan dengan Riza Susilawati binti M.Tasir, bahwa putusan hakim memutuskan nafkah tiga orang anak sebesar Rp. 300.000 (tiga Ratus ribu rupiah) perbulan sampai anak tersebut dewasa berumur 21 tahun. Hasilnya melalui wawancara penulis dengan mantan isteri, putusan pengadilan agama itu tidak dilaksanakan oleh mantan Suami, nafkah anak yang sebesar Rp. 300.000 (tiga ratus ribu rupiah) perbulanya tidak pernah dibayarkan sama sekali oleh mantan suami sesuai dengan keputusan Pengadilan Agama Pariaman. ${ }^{33}$ Kemudian penulis melakukan wawancara langsung dengan mantan suami, ia mengatakan:

"Saya mengetahui jumlah kewajiban membayar nafkah anak itu sebesar Rp. 300.000 (tiga ratus ribu rupiah) perbulan sampai anak tersebut dewasa berumur 21 tahun. Adapun ungkapan dari mantan isteri saya itu benar tentang pembayaran nafkah anak perbulannya tidak pernah saya bayar kepada mantan isteri sampai sekarang". Kemudian yang menjadi kendala adalah: "(1) Karena saya tidak mengakui bahwa itu anak kandung saya. Sebab, waktu berumah tangga mantan isteri saya lari dari rumah saya dan pindah ke rumah orang tuanya selama tiga bulan dan tidak pernah kembali. Kemudian selama tiga bulan itu ternyata mantan isteri saya hamil dan akhirnya melahirkan. Adapun pengakuan saya terhadap anak itu di Pengadilan Agama Pariaman hanyalah untuk melancarkan proses sidang di pengadilan agama Pariaman, sehingga mendapatkan akta cerai. Jika dipermasalahkan tentang status anak maka proses perkaranya menjadi panjang dan lama. (2) Karena faktor ekonomi. saya tidak memiliki uang dan sumber mata pencarian yang tetap, hanya sebagai pedagang kacil-kecilan. (3) Saya sudah memiliki isteri baru dan anak yang ditinggal mati oleh steri pertama. Sebab, untuk menafkahi isteri dan anak saja belum cukup, apalagi untuk anak dari mantan isteri saya itu. ${ }^{34}$ 


\section{http://Jurnal.iain-padangsidimpuan.ac.id/index.php/elganuniylindex ISSN : 2442-6652 E-ISSN : 2580-7307}

Kelima, putusan Nomor: 0331/Pdt.G/2015/PA.Prm tentang cerai talak yang diajukan oleh Syafrilnaldi bin Amin Husini (Perabot rumah) dengan Revi Heldini Binti St. Syafaril Awal, bahwa putusan hakim memutuskan nafkah dua orang anak sebesar Rp. 800.000/bulan sampai anak tersebut dewasa berumur 21 tahun. Hasilnya melalui wawancara penulis dengan mantan isteri, mantan suami hanya membayar sebesar Rp. 200.000 (dua ratus ribu rupiah) perbulannya sampai sekarang. ${ }^{35}$ Kemudian penulis mencoba untuk mewawancarai mantan suaminya, namun mantan suaminya tersebut tidak mau di wawancarai oleh penulis dengan alasan sibuk. Namun, penulis mencoba mewawancarai karyawan teman tempat ia bekerja, menurutnya sebab temannya tidak mau membayarkan nafkah anak itu adalah:

"(1)Faktor ekonomi, Sebab, mantan suami mendapat uang sesuai dengan penjualan parabot. (2) mantan suami masih merasakan sakit hati kepada mantan isteri. (3) mantan suami sudah memiliki steri baru. ${ }^{36}$

Jika diidentifikasi alasan mantan suami secara umum tidak melakukan kewajibannya adalah sebagai berikut: (1) Karena faktor ekonomi, (2) Karena faktor umur anak masih sekolah dasar/ kecil, (3) Karena mantan suami masih ada rasa sakit hati terhadap mantan isteri, (4) Karena mantan suami sudah memiliki isteri baru, (5) Karena alamat tempat anak begitu jauh dari tempat tinggal mantan suami, (6) Karena mantan suami sering keluar daerah.

Adapun kendala secara khsusus adalah: (1) Karena hakim membebankan nafkah anak terlalu banyak sehingga terasa berat bagi mantan suami untuk memberi nafkah anak karena mata pencaharian tidak tetap. (2) Karena mantan suami tidak mengakui bahwa itu anaknya, (3) Karena mantan isteri memberikan pengertian kepada anaknya bahwa ayahnya sudah meninggal dunia. (4) Karena keterlambatan pembayaran gaji di kantor.

Maka, dari ke-sepuluh putusan yang penulis teliti dan wawancarai tersebut dapat disimpulkan, bahwa para mantan suami tersebut pada hakikatnya mengetahui apa isi dari putusan Pengadilan Agama Pariaman tersebut, dan apa yang menjadi kewajiban mereka untuk di tunaikan sebagai konsekuensi dari putusan. Karena, sebahagian dari isi putusan telah dilaksanakan oleh para mantan suami meskipun tidak secara penuh sesuai perintah putusan pengadilan, dengan berbagai alasan-alasan sebagaimana di telah dijelaskan di atas. Hal ini menggambarkan bahwa para manatan suami dalam perspektif pengetahuan hukum dianggap cukup, namun yang menjadi persoalan adalah bagaimana kesadaran hukum mantan suami dalam menjalankan putusan pengadilan tersebut. Sebab, kepatuhan hukum tersebut senantiasa tergantung pada kesadaran hukum seseorang. Mantan suami akan sulit mentaati hukum atau 
putusan pengadilan tersebut jika tidak memahami substansi dari hukum itu sendiri. Sebab kesanggupan untuk memahami hukum secara logis diikuti oleh kemampuan untuk menilainya. Disinilah letak hubungan antara kesadaran hukum dengan kepatuhan hukum.

Jika diihat dari perspektif kesadaran hukum manatan suami dalam menunaikan kewajibannya terhadap anak-anaknya, sepertinya harus dilihat melalui indikator kesadaran hukum utu sendiri. Kesadaran hukum itu paling tidak ada empat indikator:

1. Pengetahuan tentang peraturan-peraturan hukum.

2. Pemahaman tentang isi peraturan-peraturan hukum.

3. Sikap terhadap peraturan-peraturan hukum.

4. Pola-pola perikelakukan hukum. ${ }^{37}$

Berdasarkan keempat indikator tersebut, pada indikator pertama dan kedua, para mantan suami dianggap cukup mengetahui sebatas tentang peraturan kewajiban membayar nafkah anak sekaligus mengetahui isi peraturan serta memahami maksud dari peraturan kewajiban membayar nafkah anak yang telah diputusakan oleh hakim Pengadilan Agama Pariaman. Namun indikator yang ketiga, mengenai sikap terhadap peraturan-peraturan hukum, Pertama, putusan Tahun 2014 dengan nama-nama mantan suami: Hermasyah, Sutri Jon, Charul, Nasrul dan Ilham Wijayah, pada umumnya mereka memberi jawaban bahwa "Pembayaran nafkah anak merupakan kewajiban dunia akhirat bagi orang tua (ayah), sampai anak itu dewasa atau berumur 21 tahun." ${ }^{38}$ Kedua, putusan Tahun 2015 dengan nama-nama mantan suami Almi, Sayfril, Afrizal, Mhd. Yusuf dan Syafrinaldi. Kata mereka (Syafril, afrizal dan Syafrinaldi), pada umumnya jawaban mereka sama, bahwa: "Pembayaran nafkah anak merupakan kewajiban dunia akhirat bagi orang tua. sampai anak itu dewasa atau berumur 21 Tahun $^{39}$

Dari jawaban para mantan suami tersebut, maka dapat disimpulkan bahwa mereka cukup mengetahui tentang kewajibanya untuk menafkahi anak, masing-masing sampai anakanaknya dewasa atau umur 21 Tahun. Hanya saja, para mantan suami tersebut tidak menunaikan kewajibannya secara penuh dan berkala sesuai dengan perintah putusan pengadilan. Oleh sebab itu jika dilihat dari indikator kesadaran hukum yang ke-empat yakni perspektif pola prilaku hukum para manatan suami, bahwa para mantan suami belum memilki kesadaran hukum yang cukup atau ketaatan hukum yang tergolong masih rendah, meskipun mereka mengetahui bahwa memberi nafkah anak sampai umur dewasa atau umur 21 Tahun adalah hukumnya wajib. 
Uraian di atas menggambarkan, bahwa putusan hakim PA Pariaman dari Tahun 2014 s/d 2015 tentang nafkah anak tidak terlaksana atau tidak efektif sesuai dengan amar putusan yang seharusnya, meskipun pasal 41 dan 45 ayat 2 UU No. 1 Tahun 1974 mewajibkan pada orang tua, terutama ayah untuk memberi nafkah pada anak sampai ia dewasa dan mandiri, dan tetap berlaku walaupun kedua orang tua si anak telah bercerai atau berpisah.

Beranjak dari putusan di atas, mengenai nafkah untuk anak para ulama mewajibkan seorang orang ayah untuk menafkahi anak perempuannya sampai anak perempuannya tersebut menikah, sedangkan terhadap anak laki-laki para ulam berbeda pendapat ada yang berpendapat hanya sampai baligh (dewasa) dan adapula yang berpendapat samapai anak yang bersangkutan mapan ${ }^{40}$ atau sudah bisa hidup mandiri.

\section{E. Penutup}

Dari penjelasan yang sudah di uraikan di atas, maka dapat disimpulakan, sebagai berikut:

1. Ayah yang diwajibkan menafkahai anak dalam putusan pengadilan dari Tahun 2014-2015 tidak melaksanakan putusan secara baik dan berkelanjutan, dengan berbagai alas an dan kendala dilapangan.

2. Kesadaran hukum Ayah dalam menafkahi anak pasca putusan pengadilan masih rendah, meskipun para Ayah tersebut mengetahui bahwa menafkahi anak pasca putusan hukumnya adalah wajib baik secara agama maupun hukum nasional.

3. Jika dilihat dari persfektif indikator kesadaran hukum para Ayah tahu dan mengerti dengan peraturan/ isi dari putusan tersebut, namun tidak mau secara penuh dan berkelanjutan dalam menafkahi anak. Hal ini disebabkan karena tidak adanya rasa takut akan adanya sanksi, ditambah lagi karena aturan tentang sanksi yang tidak ada atau tidak jelas pula.

4. Kepada orang tua diharapkan walaupun terjadi perceraian, orang tua tetap harus memenuhi hak-hak anak, karena bagaimanapun juga anak adalah tanggung jawab bapak sebagai orang tua, sebab anak membutuhkan rasa cinta dan kasih sayang.

5. Kepada orang tua perempuan (mantan isteri) jika nafkah anak yang telah ditetapkan oleh hakim sedangkan mantan suami tidak membayar, maka ajukan permohonan eksekusi ke Pengadilan Agama Pariaman, sehingga mantan suami dipaksa untuk membayar nafkah anak oleh hakim Pengadilan Agama Pariaman.

6. Kepada mantan suami (ayah) tingkatkan kesadaran hukum untuk membayar nafkah anak sebab nafkah anak kewajiban bagi mantan suami.

7. Untuk para hakim haruslah adil dalam memutuskan permasalahan nafkah anak, karena jangan sampai ayah dan ibunya yang bercerai anak yang menderita. Anak yang ditinggal cerai oleh orang tuanya harus jelas masa depannya, baik secara financial, pendidikan dan kehidupan yang layak. 
End Note :

${ }^{1}$ Abu Daud, Sunah Abu Daud, (Al-Qahirah: Dar Al-Harin, 1988/1408 H), Juz-2, h. 226.

${ }^{2}$ Al-Bukhari, Shahi al-Bukhary, Juz 3 (Beirut: dar al-Fikr, 1410 H/1990 M), Cet, Ke-6, h.193. lihat juga: Muahammad Fuad Abdul Baqi, Shahih Al-Lu'Lu’ Wal Marjan, (Jakarta, Akabar Media), 2011, h. 471.

${ }^{3}$ Ahmad Rafiq, Hukum Islam di Indonesia, (Jakarta: Raja Grafindo Persada, 2000), cet. IV, h. 237.

${ }^{4}$ Peradilan Agama Pariaman berdiri berdasarkan Keputusan Menteri Agama RI Nomor: 58 Tahun 1957, tanggal 13 November 1957 yang sekarang wilayah hukumnya meliputi Kabupaten Padang Pariaman dan Kota Pariaman. Walaupun tahun 1957 telah keluar Keputusan Menteri Agama RI tentang pembentukan Pengadilan Agama Pariaman, namun efektif beropersinya melakukan kegiatan dimulai pada tahun 1959 dengan ketua pertamanya adalah Alm. H. M. Yusuf Jamil.

${ }^{5}$ Soerjono Soekanto, Mustafa Abdullah Sosiologi Hukum Dalam Masyarakat (Jakarta: PT. Raja Grafindo Persada, 1987), h. 211.

${ }^{6}$ Soerjono Soekanto, Pokok-Pokok Sosiaologi Hukum, (Jakarta: PT. Raja Grafindo Persada, 1994), h. 147.

${ }^{7}$ Ibid, h. 298

${ }^{8}$ Otje Salman dan Anton F. Susanto, , Teori Hukum Mengingat, Mengumpulkan dan Membuka Kembali. (Bandung: PT Refika Aditama, 2004), h. 154.

9 Ahmad Tholabi Khalie, Kesadaran Hukum Masyarakat Terhadap Hukum Perkawinan, (Jakarta: Lembaga Penelitian UIN Jakarta,2009), h. 40

${ }^{10}$ Otje Salman, Kesadaran Hukum Masyarakat Terhadap Hukum Waris, cet I (Bandung: Alumni, 1993), h. 40

${ }^{11}$ Ahmad Tholabi Khalie, Op.Cit, h. 5

${ }^{12}$ Zainuddin Ali, Sosiologi Hukum (Jakarta: Sinar Grafika, 2005), h. 68

${ }^{13}$ Ibid

${ }^{14}$ Ahmad Tholabi Khalie, op.cit, h. 44

${ }^{15}$ Laporan Keadaan Perkara Bulan Januari Sampai Desember 2014 di Pengadilan Agama Pariaman.

${ }^{16}$ Zulbaiti, Wawancara, Selasa, 1 September 2015 pukul 12.00 WIB di rumah Narasumber.

${ }^{17}$ Hermasnyah, Wawancara, Selasa, 25 Nopember 2015 Pukul 12.00 WIB. di Kantor Biro UNP.

${ }^{18}$ Hendra, Wawancara, Minggu, 25 Oktober 2015 pukul 12.00 WIB di rumah Narasumber.

${ }^{19}$ Sutri Jon, Wawancara, Minggu, 25 Nopember 2015 Pukul 9.00 WIB. di Kantor Dinas Kesahtan Kabupaten Padang Pariaman.

${ }^{20}$ Yeni warti, Wawancara, Minggu, 25 Oktober 2015 pukul 13.00 WIB di rumah Narasumber.

${ }^{21}$ Raimadar, Wawancara, Senin, 23 Nopember 2015 Pukul 9.00 WIB. di rumah Narasumber. Adapun penulis ketika memohon untuk minta nomor Henpon Nasrul untuk menghubunginya. Raimaidar orang tua Nasrul tidak mau meberikannya, sebab mengangu keluarga baru Nasrul.

${ }^{22}$ Rismawati, Wawancara, Minggu, 25 Oktober 2015 pukul 15.00 WIB di rumah Narasumber.

${ }^{23}$ Chairul, Wawancara, Minggu, 23 Nopember 2015 Pukul 8.00 WIB di rumah Mertua Narasumber.

${ }^{24}$ Nera Afrianti, Wawancara, Minggu, 25 Oktober 2015 pukul 11.00 WIB di rumah Narasumber.

${ }^{25}$ Ilham Wijaya, Wawancara, Senin, 23 Nopember 2015 Pukul 18.00 WIB. di rumah Orang tua Narasumber.

${ }^{26}$ Laporan Keadaan Perkara Bulan Januari Sampai Oktober 2015 di pengadilan agama Pariaman. Narasumber.

${ }^{27}$ Rici Putri Yuliza (Mantan Isteri), Wawncara, Selasa, 1 September 2015 pukul 12.00 WIB di rumah

${ }^{28}$ Almi, Wawancara, Senin, 23 Nopember 2015 Pukul 12.00 WIB.di rumah orang Nara Sumber .

${ }^{29}$ Yuliana, Wawncara, Sinin, 26 Oktober 2015 pukul 9.00 WIB di rumah Narasumber

${ }^{30}$ Sayfril, Wawncara, Selasa, 24 Nopember 2015 pukul 8.00 WIB. di rumah Narasumber.

${ }^{31}$ Kurni Yanti, Wawncara, Sinin, 26 Oktober 2015 pukul 9.00 WIB di rumah Narasumber.

32 Afrizal, Wawancara, Minggu, 23 Nopember 2015 pukul 20.00 WIB. dimelalui henpon, sebab sudah dua kali penulis kerumah Narasumber tidak ketemu dan hanya ketemu dengan Steri barunya di rumahnya Korong Simpang Balai Kamih Nagari Kapalo Hilalang Kecamatan 2x11 Kabupaten Padang Pariaman.

${ }^{33}$ Rizasusilawati, Wawncara, Senin, 26 Oktober 2015 pukul 9.00 WIB di rumah Narasumber. 
${ }^{34}$ Mhd. Yusuf, Wanwancara, 23 Nopember 2015 Pukul 16.00 WIB. Dirumah Narasumber Korong Pasa Usang.

${ }^{35}$ Revi Heldini, Wawncara, Senin, 25 Oktober 2015 pukul 12.00 WIB di rumah Narasumber.

${ }^{36}$ Karywan, Wawncara, Selasa, 24 Nopember 2015 Pukul 10.00 WIB. di tepat kerja perabot dan informasih ini juga dibenarkan oleh mantan steri bahwa mantan suaminya sudah menikah dengan perempuan lain.

${ }^{37}$ Soerjono Soekanto, Kesadaran Hukum dan Kepatuhan Hukum, (Jakarta: Rajawali, 1982), h. 159.

${ }^{38}$ Wawancara Mantan Suami, (Hermasnyah, Wawancara, Selasa, 25 Nopember 2015 Pukul 12.00 WIB. di Kantor Biro UNP. Sutri Jon, Wawancara, Minggu, 25 Nopember 2015 pukul 9.00 WIB di Kantor Dinas Kesahtan Kabupaten Padang Pariaman. Raimadar (Ibu nasrul), Wawancara, Senin, 23 Nopember 2015 Pukul 9.00 WIB. di rumah Narasumber. Adapun ketika penulis memohon untuk meminta nomor Henpone Nasrul untuk menghubunginya. Raimaidar orang tua Nasrul tidak mau meberikannya, sebab dianggap mengangu keluarga baru Nasrul. Chairul, Wawancara, Minggu, 23Nopember 2015 Pukul 8.00 WIB. di rumah Mertua Narasumber. Ilham Wijaya, Wawancara, Senin, 23 Nopember 2015 pukul 18.00 WIB di rumah Orang tua Narasumber.)

${ }^{39}$ Wawancara mantan Suami (Almi, Wawancara, Senin, 23 Nopember 2015 Pukul 12.00 WIB. melalui henpone, berawal ketika penulis kerumah Almi, kemudian setelah samapai kerumahnya Korong Teboh Nagari Campago, orang tuanya menyampaikan Almi merantau ke Pakanbaru. Penulis wawancara dengan orang tuanya (Lamsuri) tentang nafkah anak dan orang tuanya menyampaikan lebih baik hubungi Alami karena dia yang tahu. Sayfril, Wawncara, Selasa, 24 Nopember 2015 Pukul 8.00 WIB. di rumah Narasumber. Afrizal, Wawancara, Minggu, 23 Nopember 2015 pukul 20.00 WIB melalui henpone, sebab sudah dua kali penulis ke rumah Narasumber tidak ketemu dan hanya ketemu dengan isteri barunya di rumahnya Korong Simpang Balai Kamih Nagari Kapalo Hilalang Kecamatan 2x11 Kabupaten Padang Pariaman.

40 Hendra Gunawan, "Sistem Peradilan Islam" pada Jurnal el-Qonuniy: Jurnal Ilmu-ilmu Kesyari'ahan dan Pranata Sosial Fakultas Syariah dan Ilmu Hukum IAIN Padangsidimpuan, Volume 5 Nomor 1 Edisi Januari-Juni 2019, hlm. 90-103. 


\section{DAFTAR PUSTAKA}

Daud, Abu,. Sunah Abu Daud, (Al-Qahirah: Dar Al-Harin, 1988/1408 H), Juz-2

Khalie, Ahmad Tholabi,, Kesadaran Hukum Masyarakat Terhadap Hukum Perkawinan, Jakarta: Lembaga Penelitian UIN Jakarta, 2009.

Rafiq, Ahmad,. Hukum Islam di Indonesia, Jakarta: Raja Grafindo Persada, 2000.

Al-Bukhari, Shahi al-Bukhary, Juz 3, Cet ke-6, Beirut: Dar al-Fikr, 1990.

Baqi, Muahammad Fuad Abdul,. Shahih Al-Lu'Lu' Wal Marjan, Jakarta, Akabar Media, 2011.

Gunawan, Hendra, "Sistem Peradilan Islam" pada Jurnal el-Qonuniy: Jurnal Ilmu-ilmu Kesyari'ahan dan Pranata Sosial Fakultas Syariah dan Ilmu Hukum IAIN Padangsidimpuan, Volume 5 Nomor 1 Edisi Januari-Juni 2019.

Susanto, Otje Salman dan Anton F,. Teori Hukum Mengingat, Mengumpulkan dan Membuka Kembali, Bandung: PT Refika Aditama, 2004.

Waris, cet I, Bandung: Alumni, 1993.

Soekanto, Soerjono,. Sosiologi Hukum Dalam Masyarakat, Jakarta: PT. Raja Grafindo Persada, 1987.

Rajawali, 1982.

Kesadaran Hukum dan Kepatuhan Hukum, Jakarta:

Grafindo Persada, 1994.

Zainuddin Ali, Sosiologi Hukum, Jakarta: Sinar Grafika, 2005. 